\title{
Genes and brain malformations associated with abnormal neuron positioning
}

\author{
Jeffrey J. Moffat ${ }^{\dagger}$, Minhan $\mathrm{Ka}^{\dagger}$, Eui-Man Jung and Woo-Yang Kim ${ }^{*}$
}

\begin{abstract}
Neuronal positioning is a fundamental process during brain development. Abnormalities in this process cause several types of brain malformations and are linked to neurodevelopmental disorders such as autism, intellectual disability, epilepsy, and schizophrenia. Little is known about the pathogenesis of developmental brain malformations associated with abnormal neuron positioning, which has hindered research into potential treatments. However, recent advances in neurogenetics provide clues to the pathogenesis of aberrant neuronal positioning by identifying causative genes. This may help us form a foundation upon which therapeutic tools can be developed. In this review, we first provide a brief overview of neural development and migration, as they relate to defects in neuronal positioning. We then discuss recent progress in identifying genes and brain malformations associated with aberrant neuronal positioning during human brain development.
\end{abstract}

Keywords: Neuron positioning, Brain malformation, Neuron migration, Lissencephaly, Heterotopia, Polymicrogyria, Microcephaly, Cortical dysplasia, LIS1, DCX, Reelin, TUBA1A

\section{Background}

Neuronal positioning is an integral part of the coordinated steps comprising neural circuit formation in embryonic and neonatal development [1]. This process takes place throughout the nervous system at different time points depending on the type of neuron. Although neuronal positioning and migration occurs throughout the central nervous system, we will focus on neuronal positioning in the neocortex of the developing brain. We will present basic information on the process of neuronal positioning and describe the abnormalities that may occur in the human brain. Additionally, genes associated with neuronal positioning abnormalities will be discussed.

Correct positioning of neurons by normal migration plays a critical role in establishing cognitive functions and emotion. Human cognitive activity depends on appropriate brain circuit formation. Disrupted brain wiring due to abnormal neuronal development such as improper neuronal positioning can result in brain malformations, cognitive dysfunction, and seizures [2-4]. The causes of brain malformations associated with positioning and migration

* Correspondence: wooyang.kim@unmc.edu

${ }^{\dagger}$ Equal contributors

Department of Developmental Neuroscience, Munroe-Meyer Institute, University of Nebraska Medical Center, 985960 Nebraska Medical Center, Omaha, NE 68198-5960, USA defects are varied and include genetic mutations and environmental toxins $[1,5,6]$. Studies of neuronal migration disorders have progressed due to advances in molecular genetics and brain magnetic resonance imaging. The commonly identified disorders of neuronal positioning include lissencephaly and heterotopia [7].

\section{Neural progenitors as a source of migrating neurons in the human cerebral cortex}

Neural progenitors can undergo self-renewal or give rise to neurons at the ventricular/subventricular zone in the developing cerebral cortex [8-10]. Reduced numbers of neural progenitors caused by depletion of progenitor pools or slow proliferation result in microcephaly with otherwise normal brain structure $[11,12]$. However, microcephaly can also occur in combination with a migration defect, i.e., microcephaly with pachygyria (Norman-Roberts syndrome) [13]. Thus, the disruptive functions of neural progenitor renewal and neurogenesis may interfere with later developmental aspects such as neuronal migration and positioning in the developing brain.

\section{Neuronal migration modes}

After neurons are born, they migrate from their birthplaces to their final destinations (Fig. 1). There are two

\section{Biomed Central}

(c) 2015 Moffat et al. Open Access This article is distributed under the terms of the Creative Commons Attribution 4.0 International License (http://creativecommons.org/licenses/by/4.0/), which permits unrestricted use, distribution, and reproduction in any medium, provided you give appropriate credit to the original author(s) and the source, provide a link to the Creative Commons license, and indicate if changes were made. The Creative Commons Public Domain Dedication waiver (http://creativecommons.org/publicdomain/zero/1.0/) applies to the data made available in this article, unless otherwise stated. 


\section{A Radial migration}

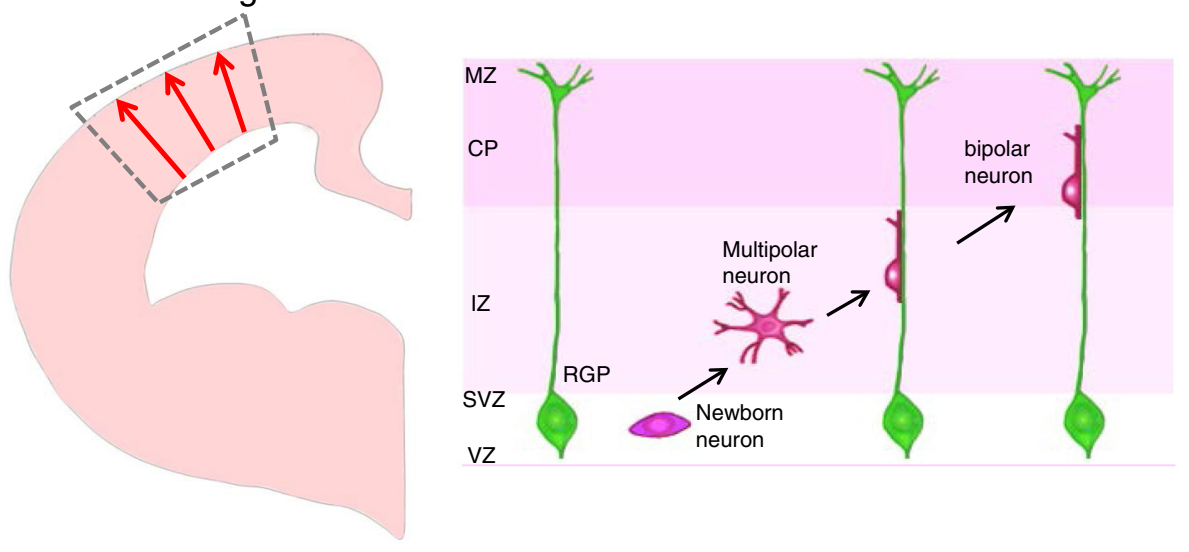

\section{B Tangential migration}
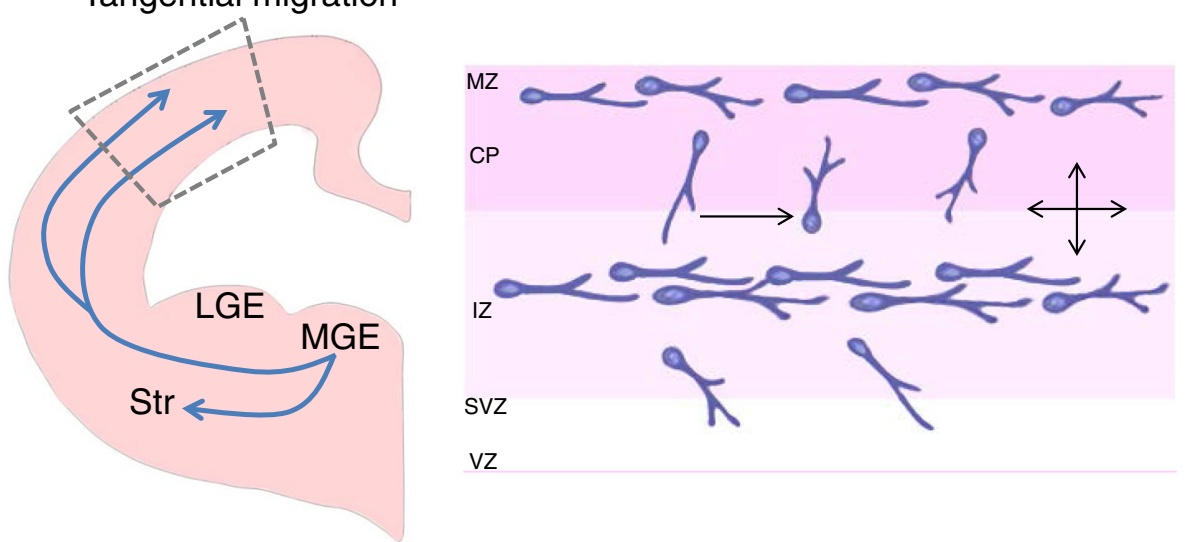

Fig. 1 Two modes of neuronal migration in the developing brain. a Radial migration. Excitatory pyramidal projection neurons migrate from the ventricular zone to the cortical plate in the developing brain. The right panel shows what happens in the rectangular box in the left panel. Newly-born neurons from radial glial progenitors (RGP) at the ventricular zone (VZ) migrate along the radial processes of RGPs. MZ: marginal zone. CP: cortical plate. IZ: intermediate zone. SVZ: subventricular zone. b Tangential migration: Interneurons originate from distinct proliferative zones in the developing brain. Inhibitory interneurons are born in the medial ganglionic eminence (MGE) of ventral brain and migrate in multiple streams into the cerebral wall. Once interneurons reach appropriate spots in the cerebral cortex, they establish their final positions by local adjustment of radial and tangential movement. Unlike pyramidal neurons, these neurons extend multiple leading branches during migration. LGE: lateral ganglionic eminence. LGE: lateral ganglionic eminence. Str: striatum

types of embryonic neuronal migration: radial and tangential. The migration of excitatory pyramidal neurons from the cortical ventricular zone (where they are born) is an example of radial migration (Fig. 1a). These neurons migrate into the cortical plate alongside radial glial processes [14-17]. The layers of the cortex form in an "inside-out" manner with later-born pyramidal neurons migrating past earlier-born predecessors in the cortical plate so that they are more superficial in their final position than earlier born neurons [5, 18-20]. In humans, neuronal migration takes place predominantly between 12 and 20 weeks in gestation. The migration of inhibitory interneurons (GABAergic neurons) from the medial ganglionic eminence of the ventral telencephalon (where they are born) is an example of tangential migration (Fig. 1b). Interneurons migrate tangentially to the dorsal telencephalon and then change direction to enter the cortical plate radially [20-23]. Subsets of these cells display ventricle-directed migration followed by radial movement to the cortical plate. Thus, neuronal migration determines the positioning of developing neurons into cortical layers and thereby is important in generating lamina-specific neural circuits. Normal development and function of the neocortex critically depends on the coordinated production and positioning of excitatory and inhibitory neurons [24-27]. Abnormal neuronal migration can arrest different types of neurons at the wrong positions along the migratory path resulting in brain malformations and neurological disorders.

In addition to these well-defined modes of embryonic neuronal migration, a limited number of neurons and neuronal precursors have been shown to migrate and 
Table 1 Brain malformations and genes associated with abnormal neuron positioning

\begin{tabular}{|c|c|c|c|}
\hline Type & Gene & Location & Description \\
\hline \multicolumn{4}{|l|}{ Lissencephaly type I } \\
\hline Lissencephaly (Autosomal dominant) & LIS1 & $17 p 13.3$ & Microtubule-associated protein \\
\hline $\begin{array}{l}\text { Isolated lissencephaly sequence (ILS) or subcortical band } \\
\text { heterotopia (SBH) }\end{array}$ & TUBA1A & $12 q 13.12$ & Constituent of microtubules \\
\hline Miller-Dieker syndrome & LIS1 + YWHAE & $17 p 13.3$ & Microtubule-associated protein \\
\hline \multicolumn{4}{|l|}{ Lissencephaly (X-linked) } \\
\hline ILS or SBH & $\mathrm{DCX}$ & $\begin{array}{l}X q 22.3- \\
q 23\end{array}$ & Microtubule-associated protein \\
\hline X-linked lissencephaly with abnormal genitalia & ARX & Xp21.3 & Transcription factor \\
\hline \multicolumn{4}{|l|}{ Lissencephaly (Autosomal recessive) } \\
\hline \multirow[t]{2}{*}{ Lissencephaly with cerebellar hypoplasia $(\mathrm{LCH})$ group b } & RELN & $7 q 22$ & Extracellular matrix serine protease \\
\hline & VLDLR & $9 q 24$ & $\begin{array}{l}\text { Binds VLDL and transports it into cells by } \\
\text { endocytosis }\end{array}$ \\
\hline \multicolumn{4}{|l|}{ Lissencephaly type II: Cobblestone complex (Autosomal recessive) } \\
\hline $\begin{array}{l}\text { Fukuyama congenital muscular dystrophy or Walker-Warburg } \\
\text { syndrome (WWS) }\end{array}$ & FKTN & $9 q 31.2$ & Involved in glycosylation \\
\hline \multirow[t]{4}{*}{ Muscle-eye-brain disease (MEB) or WWS } & POMT1 & $9 q 34.13$ & Protein-O-mannosyltransferase 1 \\
\hline & РOMT2 & $14 q 24.3$ & Protein-O-mannosyltransferase 2 \\
\hline & POMGNT2 & $3 p 22.1$ & O-linked mannose acetylglucosaminyltransferase \\
\hline & FKRP & $19 q 13.32$ & Involved in glycosylation \\
\hline \multirow[t]{2}{*}{ MEB } & LARGE & $22 q 12.3$ & Glycosyltransferase \\
\hline & POMGnT1 & $1 \mathrm{p} 34.1$ & Participates in O-mannosyl glycosylation \\
\hline Bilateral frontoparietal polymicrogyria & GPR56 & $16 q 21$ & G protein-coupled receptor 56 \\
\hline CEDNIK syndrome & SNAP29 & $22 q 11.21$ & Synaptosomal-associated protein \\
\hline \multirow[t]{7}{*}{ Muscular dystrophy } & ISPD & $7 q 21.2$ & Required for protein O-linked mannosylation \\
\hline & GTDC2 & $3 p 22.1$ & O-linked mannose acetylglucosaminyltransferase \\
\hline & TMEM5 & $12 q 14.2$ & Glycosyltransferase function \\
\hline & B3GALNT2 & $1 \mathrm{q} 42.3$ & Beta-1,3-N-acetylgalactosaminyltransferase \\
\hline & SGK196 & $8 q 11.21$ & Protein O-mannose kinase \\
\hline & B3GNT1 & $11 q 13.2$ & $\begin{array}{l}\text { Synthesis of the linear poly-N- } \\
\text { acetyllactosaminoglycans }\end{array}$ \\
\hline & GMPPB & $3 p 21.31$ & GDP-mannose pyrophosphorylase \\
\hline \multicolumn{4}{|l|}{ Polymicrogyria } \\
\hline & TUBB2 & $6 \mathrm{p} 25$ & Major constituent of microtubules \\
\hline & GPR56 & $16 q 21$ & G protein-coupled receptor 56 \\
\hline & SRPX2 & Xq22.1 & Plays a role in angiogenesis \\
\hline & TBR2 & $3 p 24.1$ & Transcriptional activator \\
\hline & PAX6 & $11 \mathrm{p} 13$ & Transcription factor \\
\hline & KIAA1279 & 10q22.1 & Organization of axonal microtubules \\
\hline & RAB3GAP1 & $2 q 21.3$ & RAB3 GTPase Activating Protein Subunit \\
\hline Adams-Oliver syndrome (AOS) & ARHGAP31 & $3 q 13.33$ & Required for cell spreading \\
\hline AOS & RBPJ & $4 p 15.2$ & Plays a central role in Notch signaling \\
\hline AOS & DOCK6 & 19p13.2 & Atypical guanine nucleotide exchange factors \\
\hline AOS & EOGT & $3 p 14.1$ & EGF domain-specific GlcNAc transferase \\
\hline AOS & $\mathrm{NOTCH} 1$ & $9 q 34.3$ & Play multiple roles during development \\
\hline
\end{tabular}


Table 1 Brain malformations and genes associated with abnormal neuron positioning (Continued)

\begin{tabular}{|c|c|c|c|}
\hline Heterotopia & & & \\
\hline Heterotopia (X-linked Autosomal dominant) & & & \\
\hline Classical bilateral periventricular heterotopia $(\mathrm{PH})$ & FLNA & $\mathrm{Xq} 28$ & Actin-binding protein \\
\hline PH with fragile- $X$ syndrome & FMR1 & Xq27.3 & Translation repressor \\
\hline PH and Williams syndrome & WBSCR16 & $7 q 11.23$ & Guanine nucleotide exchange factor \\
\hline $\mathrm{PH}$ & PVNH3 & $5 p 15.1$ & Periventricular Nodular Heterotopia 3 \\
\hline $\mathrm{PH}$ & PVNH5 & $\begin{array}{l}5 q 14.3- \\
q 15\end{array}$ & Periventricular Nodular Heterotopia 5 \\
\hline Heterotopia (Autosomal recessive) & & & \\
\hline PH with microcephaly & ARFGEF2 & $20 q 13.13$ & Intracellular vesicular trafficking \\
\hline PH with Donnai-Barrow syndrome & LRP2 & $2 q 31.1$ & Low density lipoprotein-related protein 2 \\
\hline Microcephaly & & & \\
\hline & WDR62 & $19 q 13.12$ & Required for cerebral cortical development \\
\hline & KIAA1279 & $10 q 22.1$ & Organization of axonal microtubules \\
\hline & RAB3GAP1 & $2 q 21.3$ & RAB3 GTPase Activating Protein Subunit \\
\hline & ARFGEF2 & $20 q 13.13$ & Intracellular vesicular trafficking \\
\hline Focal cortical dysplasia & & & \\
\hline & TSC1 & $9 q 34.13$ & Negatively regulating mTORC signaling \\
\hline & TSC2 & $16 p 13.3$ & Negatively regulating mTORC signaling \\
\hline Hemimegalencephaly & & & \\
\hline & PIK3CA & $3 q 26.32$ & $\begin{array}{l}\text { Serine/threonine kinase - component of } \\
\text { PI3K/AKT signaling }\end{array}$ \\
\hline & AKT3 & $1 q 44$ & $\begin{array}{l}\text { Serine/threonine kinase - component of } \\
\text { PI3K/AKT signaling }\end{array}$ \\
\hline & MTOR & $1 p 36.22$ & $\begin{array}{l}\text { Serine/threonine kinase - component of } \\
\text { PI3K/AKT signaling }\end{array}$ \\
\hline
\end{tabular}

differentiate in the early postnatal rodent and human cerebellum and hypothalamus [28, 29]. Another, more extensive mode of neuronal migration has been observed in adult rodents and non-human primates, in which neuronal precursors migrate along glial projections from the subventricular zone into the olfactory bulbs. This particular passage is referred to as the rostral migratory stream (RMS) [28-30], which continues well into adulthood, but has not been observed in humans [28, 31]. In the RMS, neuronal precursors migrate via a "tunnel" made up of astrocytes into the olfactory bulb, where they then radially migrate in a glial-independent manner toward the glomeruli and differentiate. The majority of these cells eventually become inhibitory neurons, mainly GABAergic granule neurons [28, 32]. Because the application of research tools is currently limited in humans, there is still ongoing debate about whether the RMS exists in humans [28, 31, 32].

In this review we will focus solely on brain malformations thought to be due to abnormal embryonic neuronal migration, although many of the genes and proteins discussed are no doubt involved in both embryonic and postnatal neuronal migration. It is important, however, that further research be done to understand the mechanisms of neuronal migration and the maintenance of neuronal precursor pools in adults, because of the potential to promote regeneration and repair in individuals with neuronal positioning disorders, neurodegenerative disorders, and severe brain injuries.Brain malformations and genes associated with abnormal neuron positioning are listed in Table 1.

\section{Genes and brain malformations associated with defective neuron positioning}

Type I lissencephaly

Perhaps the best known type of neuronal migration disorder is lissencephaly, "smooth brain". It is a brain malformation characterized by the absence of gyri and sulci $[7,33]$. Most individuals with this condition also present with microcephaly (small head). Although the symptoms vary, they often feature seizures, intellectual disability, developmental delays, poor motor function, difficulties with feeding, and swelling in the extremities. 


\section{LIS1 and DCX}

Mutations in lissencephaly 1 (LIS1) and doublecortin $(D C X)$ have been shown to cause type I lissencephaly (Table 1). This disorder is often associated with axon outgrowth and guidance defects such as agenesis of the corpus callosum [34]. Neuronal positioning and further differentiation may coordinate to develop the pathogenesis of lissencephaly. Classic lissencephaly (type I) includes isolated lissencephaly and subcortical band heterotopia ("double cortex") which are caused by $D C X$ mutations [33, 35]. In addition, heterozygous mutation of Lis1 in mice has been shown to impair normal neuron positioning and synaptogenesis in the amygdala [36]. Interestingly, there is a skewed sex ratio in subcortical band heterotopia and isolated lissencephaly. Females with a mutation affecting one copy of the $D C X$ gene usually develop subcortical band heterotopia while males with one $D C X$ gene mutation show isolated lissencephaly [37-41]. Males with subcortical band heterotopia or females with isolated lissencephaly are rarely reported $[42,43]$.

$D C X$ encodes a microtubule-associated protein that stabilizes microtubules and causes bundling [44-46]. This is an important molecule in neuron migration and neurite growth in the developing brain [47-49]. DCX is expressed in neuronal precursor cells and immature neurons during brain development and in the adult hippocampus. More importantly, $D C X$ is associated with the neuronal migration disorders, lissencephaly, pachygyria, and subcortical band heterotopia [37, 38, 41, 50-52]. Mutations in $D C X$ prevent neurons from migrating into the cortical plate [45]. Abnormal microtubule functions dependent on $D C X$ appear to underlie lissencephaly because pathological mutations in $D C X$ prevent its product binding and subsequent stabilization of microtubules $[53,54]$.

Miller-Dieker syndrome is characterized as a congenital brain malformation due to the microdeletion of chromosome 17p13.3 including the LIS1 gene, which can also cause classical lissencephaly [37, 41, 51, 55-58]. LIS1 encodes a dynein-binding protein and controls mitotic spindle orientation in neural cells [59-61]. The most common type of mutation is a deletion of a single copy of the gene, resulting in haploinsufficiency. Individuals with LIS1 mutations have not only lissencephaly, but often show other pathological features including corpus callosum hypoplasia and ventricle enlargement $[58,62]$. These anatomical abnormalities correlate with the critical roles of LIS1 in neuronal migration and axon formation $[57,58,63]$. In contrast to lissencephaly caused by mutations in DCX, LIS1 mutations preferentially affect the parieto-occipital cortex [37, 41, 64]. Mutations in LIS1 and $D C X$ account for approximately $85 \%$ of patients with the classic form of lissencephaly [37, 41, 65].

\section{YWHAE}

Tyrosine 3-Monooxygenase/Tryptophan 5-Monooxygenase Activation Protein, Epsilon (YWHAE) is another gene that encodes a microtubule-associated protein and is located just $1 \mathrm{Mb}$ away from LIS1 on chromosome 17p. YWHAE also participates in the LIS1 pathway, and homozygous deletion of mouse Ywhae leads to neuronal migration defects. Large deletions of the 17p13.3 region (which contains both YWHAE and LIS1) causes Miller-Dieker syndrome, and patients with this deletion display more severe neuronal migration defects than those observed in LIS1 mutant heterozygote-caused lissencephaly [54].

\section{TUBA1A and TUBB2}

Tubulin Alpha 1a (TUBA1A) and Tubulin Beta 2 (TUBB2) encode critical structural subunits of microtubules that are enriched during brain development [66]. TUBA1A mutations are identified in $1 \%$ of classic lissencephaly and $30 \%$ of lissencephaly with cerebellar hypoplasia [67-69]. Meanwhile, TUBB2 mutations are associated with symmetric polymicrogyria and pachygyria [70]. Guanosine triphosphate (GTP) contributes to microtubule assembly by binding to soluble tubulin heterodimers [71]. Mutations in these tubulin genes prevent microtubule polymerization. For example, the S140G mutation reduces the protein capacities of GTP binding and native heterodimer formation, thus preventing polymerization of microtubules and neuronal migration in mice [72]. In contrast to TUBA1A and $T U B B 2, T U B B 3$ is important in axon guidance and microtubule dynamics, but dispensable for neuronal migration [73].

\section{ARX}

Aristaless related homeobox $(A R X)$ is a homeoboxcontaining gene expressed in the nervous system during development [74-76]. ARX mutations are associated with an X-linked lissencephaly syndrome with infantile spasms as well as abnormal genitalia [77-79]. Mutations that cause lissencephaly often lead to premature truncation or alter the DNA binding domain of the protein (homeodomain) [80, 81]. Studies using human brain samples and animal models have revealed that $A R X$ is important in proliferation of radial and intermediate neural progenitors, and migration of excitatory cortical neurons $[75,79,80,82]$. It also critically controls the migration and further differentiation of inhibitory GABAergic interneurons [79, 80, 82-86]. This is consistent with the fact that ARX is expressed in the ganglionic eminence and cortical ventricular zone where interneuron and pyramidal neural progenitors reside, respectively [79]. Furthermore, ARX overexpression promotes the development of tangentially migrating interneurons [82, 86]. However, some mutations disrupt neuronal excitability without affecting 
neuronal migration or the cortical lamination pattern in the brain [87].

\section{RELN}

Reelin (RELN) and its cellular receptor very-lowdensity-lipoprotein receptor (VLDLR) are cellular signaling components. RELN is required for neuronal migration in the developing cortex [54, 88-91]. Accordingly, VLDLR critically regulates neuronal migration and positioning in the cerebral cortex [92]. RELN promotes hippocampal dendrite development through the VLDLRDab1 pathway as well [93]. Mutations in these genes are known to cause lissencephaly with cerebellar hypoplasia [54, 94-96]. The RELN mutation syndrome appears to be inherited in an autosomal-recessive pattern and these patients appear to be relatively rare [94]. Mutations in $V L D L R$ can cause combinations of ataxia, intellectual disability, and quadrupedal gait [97].

\section{Type II lissencephaly}

Type II lissencephaly is often referred to as "cobblestone lissencephaly" because patients typically only have regional agyria. It is associated with WalkerWarburg syndrome, a heterogeneous group of muscular dystrophy-dystroglycanopathy (MDDG) conditions that can be caused by homozygous mutations in the genes FKTN (Fukuyama syndrome), POMT2 and POMGnT1 (muscle-eye-brain disease), as well as POMGNT2, FKRP, LARGE, ISPD, GTDC2, TMEM5, B3GALNT2, SGK196, B3GNT1, and GMPPB [98-101]. In type II lissencephaly, there are no layers present in the cortex. Instead, irregularities in neuronal placement exist. Abnormal glycosylation of matrix proteins in the cerebral cortex is thought to cause these migration defects $[102,103]$.

Loss of function mutations in SNAP29, which encodes a member of the SNARE protein family, has been shown to cause CEDNIK (cerebral dysgenesis, neuropathy, ichthyosis and keratoderma) syndrome [104]. Brain MRI scans of CEDNIK syndrome patients revealed apparent extensive aberrant neuronal migration, as evidenced by corpus callosum abnormalities and cortical dysplasia, along with pachygyria, polymicrogyria and cobblestone lissencephaly [105]. Migration defects in SNAP29 mutants may be attributed to an impairment in $\beta 1$-integrin [106].

\section{Polymicrogyria}

Polymicrogyria is a neurological condition characterized by an excessive number of small and fused gyri separated by shallow sulci in the cerebral cortex compared to normal cerebral surfaces [6,70,107, 108]. Mutations in the TUBB2, GPR56, and WDR62 genes are associated with this condition [70, 109-111]. Polymicrogyria develops between the late stage of neuronal migration and the early point of cortical organization $[108,112]$.
Patients with polymicrogyria show a layer of intracortical laminar necrosis and subsequent disruption of late cortical lamination. Some cerebral cortices have a molecular layer that does not align along the borders of gyri. Neurons under this layer have a radial distribution without laminar organization [111]. Polymicrogyria most often occurs as an isolated feature. However, it is sometimes shown in multiple genetic syndromes associated with intellectual disability and birth defects including 22q11.2 deletion syndrome, Adams-Oliver syndrome (genetically heterogeneous, caused by mutations in ARHGAP31, RBPJ, DOCK6, EOGT, and NOTCH1), Aicardi syndrome, Galloway-Mowat syndrome, Joubert syndrome, and Zellweger spectrum (peroxisome biogenesis disorders including Zellweger syndrome, neonatal adrenoleukodystrophy, and Refsum disease) $[111,113-116]$. The clinical features and etiology of polymicrogyria are heterogeneous. Most patients with polymicrogyria develop epilepsy during their early childhood (4-12 years of age). Seizures are resistant to pharmacological drugs in many cases of polymicrogyria.

\section{TBR2 and PAX6}

Pax6, which encodes paired box protein 6, is highly expressed in radial glia, but is downregulated as they transition into intermediate progenitor cells during neurogenesis. This coincides with an upregulation of $T$ brain gene-2 (TBR2) that persists until intermediate neural progenitor cells differentiate into postmitotic neurons [117]. Mutations in TBR2 and PAX6 have been shown to cause polymicrogyria, due to defects in neuronal migration, differentiation and proliferation of neural progenitors [118-120].

\section{SRPX2}

$S R P X 2$ encodes a secreted sushi-repeat containing protein that is expressed in neurons. A rare missense mutation in the SRPX2 gene causes bilateral perisylvian polymicrogyria, though its mechanism in development of this disease remains unknown. SRPX2 is expressed in humans in the fetal and adult brain, whereas in mice, measurable expression does not begin until birth [121]. This poses problems for further studies into the role of SRPX2 in brain development and neuronal migration.

\section{KIAA1279}

Homozygous nonsense mutations in the KIAA1279 gene cause Goldberg-Shprintzen syndrome, which is characterized by bilateral generalized polymicrogyria, microcephaly, mental retardation, and an enteric nervous disorder [122]. KIAA1279 encodes a kinesin family member-binding protein, but its role in the pathology of Goldberg-Shprintzen syndrome is still unknown [123, 124]. It was recently shown, however, that KIAA1279 
co-localizes with both $\alpha$-tubulin and F-actin. Relatedly, KIAA1279 is also involved in neurite outgrowth. Inhibition of KIAA1279 expression using siRNA leads to dendritic spine depletion and a decrease in neurite length in neuroblastoma cells, and overexpression of KIAA1279 triggers an increase in dendritic spine and neurite length, compared to controls [123].

\section{RAB3GAP}

Rab3 GTPase-activating protein (RAB3GAP) is a heterodimeric complex comprised of a catalytic subunit (RAB3GAP1) and a slightly larger non-catalytic subunit (RAB3GAP2). This complex acts as a guanine-nucleotide exchange factor for the RAB18 protein [125]. RAB18 is also regulated by the GTP-activating protein TBC1D20 [126]. Mutations or dysregulation of RAB18 causes Warburg Micro syndrome, which is characterized by ocular and neurodevelopmental abnormalities, including polymicrogyria, microcephaly, pachygyria, polymicrogyria, and hypoplasia of the corpus calossum. It is unclear by what molecular mechanism RAB18 dysfunction leads to these neurodevelopmental aberrations, but mutations to RAB3GAP1, RAB3GAP2, TBC1D20 and RAB18 are all sufficient to cause these symptoms $[125,126]$. It has recently been demonstrated, that TBC1D20 activity fosters extraction of RAB18 from the ER membrane and facilitates its retargeting for the cis-Golgi. In the cis-Golgi, it appears that the RAB3GAP complex recruits and stabilizes the RAB18 protein [126].

\section{Heterotopia}

In addition to cortical gyration disorder, dysfunctional neuronal migration can lead to the development of neuronal population in aberrant locations. Periventricular nodular heterotopia is one of these neuronal migration disorders [5-7, 107, 108]. In this case, failed migration leads to the formation of heterotopic neurons along the ventricular surfaces in the brain. Therefore, the neurons are positioned deeper than those found in type I lissencephaly. This malformation can be bilateral or unilateral. Periventricular heterotopia is diagnosed with magnetic resonance imaging (MRI) and seizure symptoms. Affected individuals usually have normal intelligence, although some have mild intellectual disability. Some cases of periventricular heterotopia are associated with dyslexia [127]. For example, a specific reading fluency deficit is identified in a heterogeneous group of patients with periventricular heterotopia who have seizures, heterotopic neurons, and disrupted cortical connectivity $[127,128]$.

\section{FLNA}

The most common genetic cause of periventricular heterotopia is the X-linked dominant inheritance of Filamin A (FLNA) gene mutations [129, 130]. The FLNA gene encodes an F-actin-binding cytoplasmic protein involved in neurogenesis and neuronal migration in the developing brain $[131,132]$. FLNA crosslinks actin filaments into the cortical cytoskeleton. FLNA mutations are associated with classical bilateral periventricular nodular heterotopia and account for the majority of X-linked inherited periventricular heterotopias [6, 133, 134]. FLNA regulates neuronal migration in the cerebral cortex [131]. Mutations in the human FLNA gene may also cause connective tissue disorders associated with Ehlers-Danlos syndrome which include extremely flexible joints, stretchable skin, and fragile blood vessels [135]. Unsurprisingly, patients with Ehlers-Danlos syndrome also frequently present with epilepsy and periventricular heterotopia [136].

\section{PVNH3 and PVNH4}

In addition to FLNA mutations, duplications and deletions in chromosome 5 which includes Periventricular Nodular Heterotopia 3 (PVNH3) and Periventricular Nodular Heterotopia 5 (PVNH5) have been seen in patients with periventricular heterotopia without mutations in other causative genes [137]. Periventricular nodular heterotopia is also found in individuals with other conditions, including Ehlers-Danlos syndrome [135].

\section{FMR1}

CGG trinucleotide repeat expansion of the FMR1 gene causes fragile $\mathrm{X}$ syndrome in humans and has also been shown to lead to periventricular heterotopia. This may indicate a role for the FMR1 protein in neuronal migration [138].

\section{ARFGEF2}

ADP-ribosylation factor guanine exchange factor 2 (ARFGEF2) encodes a protein kinase A-anchoring protein that regulates GDP-GTP conversion of ADPribosylation factor $[139,140]$. Via mediation of Filamin A signaling, ARFGEF2 is involved in neuronal migration through the regulation of vesicle trafficking. Mutations in ARFGEF2 also cause bilateral periventricular nodular heterotopia, as well as putaminal hyperintensity and microcephaly $[131,141]$.

\section{LRP2}

Low density lipoprotein-related protein 2 (LRP2) encodes megalin, a multiligand receptor. Mutations to LRP2 cause Donnai-Barrow syndrome, which is associated with several neurological and cranial abnormalities, including periventricular nodular heterotopia [142]. Megalin facilitates the endocytosis of sonic hedgehog (Shh) in embryonic neuroepithelium [143]. Furthermore, megalin has been shown to bind and sequester Shh in the 
forebrain, and mediate Shh-Ptch endocytosis [144]. This key interaction with Shh signaling in the developing brain could explain the aberrant neuronal positioning observed in patients with $L R P 2$ mutations.

\section{Focal cortical dysplasia}

Focal cortical dysplasia is a rare lamination abnormality in the cerebral cortex characterized by focal cortical thickening or thinning, focal atrophy, or blurring of the gray-white junction $[6,145]$. Focal cortical dysplasia is the most common cause of medically refractory epilepsy in the pediatric population [145]. Defective regulation of neuronal migration or cell death is speculated to cause focal cortical dysplasia [146, 147]. There are three types of focal cortical dysplasia [34, 145, 148, 149]. Type I focal cortical dysplasia is found in the temporal lobe of the brain. This type is late onset, thus often seen in adults. Patients with this condition show mild symptoms. Type II focal cortical dysplasia, however, is mostly found in children and the clinical symptoms are more severe. There are more extensive changes outside the temporal lobe with predilection for the frontal lobes. Type III focal cortical dysplasia occurs in combination with hippocampal sclerosis, epilepsy-associated tumors, vascular malformation, or epileptogenic lesions. Studies have suggested that mutations in the TSC1 (Tuberous Sclerosis 1) gene is associated with the formation of focal dysplasia [145, 150, 151]. Changes in Wnt and Notch signaling components that control proper neuronal migration are also found in focal cortical dysplasia $[145,152]$.

\section{Hemimegalencephaly}

Hemimegalencephaly is implicated in neuronal positioning abnormality. Hemimegalencephaly features one side of the brain that is abnormally larger than the other $[6,108,153]$. The unusual enlargement of the brain causes seizures and intellectual disability [154]. This condition is thought to take place when neurons are abnormally organized due to defective migration in the developing cerebral cortex because the enlarged hemisphere usually shows focal or diffused regions of polymicrogyria, pachygyria, and heterotopia [155-159]. However, whether abnormal neuronal migration during development causes hemimegalencephaly is unclear. Using exome sequencing, recent studies have identified de novo germline and somatic mutations of PI3K-AKT-mTOR components (PIK3CA, AKT3, and MTOR genes) in patients with hemimegalencephaly [160-164]. Thus, hemimegalencephaly may be a genetically mosaic disease caused by abnormal PI3K-AKT-mTOR signaling. In addition to its role in neuronal migration, PI3K-AKT-mTOR signaling critically regulates neural progenitor proliferation and neurogenesis [32, 165-168].

\section{Conclusions}

Recent advances in neurogenetics and brain imaging have revealed genes responsible for neuronal migration disorders. Efforts have been made to characterize the functions of the causative genes and develop appropriate animal models. Still, research that overcomes these disorders is only in the beginning stage of work. Further human genetic analysis and neurobiological studies should expand our understanding of the pathogenesis of neuronal migration disorders, which will help to develop therapeutic strategies for these disorders in the future.

\section{Abbreviations}

AKT: RAC-alpha serine/threonine-protein kinase; ARGEF2: ADP-ribosylation factor guanine exchange factor 2; ARHGAP31: rho GTPase Activating Protein 31; ARX: Aristaless-related homeobox; B3GALNT2: Beta-1,3-Nacetylgalactosaminyltransferase 2; B3GNT1: Beta-1,3-N-

acetylglucosaminyltransferase 1; CEDNIK: Cerebral dysgenesis-neuropathyichthyosis-palmoplantar keratoderma; CP: Cortical plate; DCX: Doublecortin; DOCK6: Dedicator of cytokinesis 6; EOGT: EGF domain-specific O-linked NAcetylglucosamine (GIcNAc) transferase; FKRP: Fukutin related protein; FKTN: Fukutin; FLNA: Filamin A; FMR1: Fragile X mental retardation 1; GMPPB: GDP-mannose pyrophosphorylase B; GPR56: G protein-coupled receptor 56; GTDC2: Glycosyltransferase-like domain containing 2; GTP: Guanosine triphosphate; ILS: Isolated lissencephaly sequence; ISPD: Isoprenoid synthase domain containing; IZ: Intermediate zone; KIAA1279: KIF1 binding protein (KIF1BP); LARGE: Like-glycosyltransferase: LCH: Lissencephaly with cerebellar hypoplasia; LGE: Lateral ganglionic eminence; LIS1: Lissencephaly 1; LRP2: Low density lipoprotein receptorrelated protein 2; MEB: Muscle-eye-brain disease; MRI: Magnetic resonance imaging; mTOR: Mechanistic target of rapamycin; MGE: Medial ganglionic eminence; MZ: Marginal zone; PAX6: Paired box 6; PH: Periventricular heterotopia; PI3K: Phosphatidylinositol-4, 5-bisphosphate 3-kinase; POMGnT1: Protein O-linked mannose $\mathrm{N}$-acetylglucosaminyltransferase 1; POMGnT2: Protein O-linked mannose $\mathrm{N}$-acetylglucosaminyltransferase 2; POMT2: Protein-O-mannosyltransferase 2; PVNH3: Periventricular nodular heterotopia 3; PVNH4: Periventricular nodular heterotopia 4; RAB18: RAB18, member RAS oncogene family; RAB3GAP: Rab3 GTPase activating protein; RBPJ: Recombination signal binding protein for immunoglobulin kappa J region; RELN: Reelin; RGP: Radial glial progenitors; RMS: Rostral migratory stream; SBH: Subcortical band heterotopia; SGK196: Protein-O-mannose kinase (POMK); SNAP29: Synaptosomal-associated protein, 29kDa; SNARE: Soluble NSF Attachment Protein Receptor; SRPX2: Sushi-repeat containing protein, X-linked 2; SVZ: Subventricular zone; TBC1D20: TBC1 domain family, member 20; TBR2: T-brain gene-2; TMEM5: Transmembrane protein 5; TSC1: Tuberous sclerosis 1; TSC2: Tuberous sclerosis 2;

TUBA1A: Tubulin, alpha 1a; TUBB2: Tubulin, beta 2; TUBB3: Tubulin, beta 3; VLDR: Very-low-density-lipoprotein receptor; VZ: Ventricular zone;

WBSCR16: Williams-Beuren syndrome chromosome region 16; WDR62: WD repeat domain 62; WWS: Walker-Warburg syndrome; YWHAE: Tyrosine 3monooxygenase/Tryptophan 5-Monooxygenase Activation Protein, Epsilon.

\section{Competing interests}

The authors declare that they have no competing interest.

\section{Authors' contributions}

$J M, M K, E J$, and WK analyzed the published studies and wrote the paper. WK conceived the study. All authors read and approved the final manuscript.

\section{Acknowledgements}

We thank Drs. Robert Norgren and Shelley Smith for valuable advice and comments on the manuscript. This work was supported by an award from the National Institute of Neurological Disorders and Stroke of the National Institutes of Health under award number R01NS091220 and an Institutional Development Award (IDeA) from the National Institute of General Medical Sciences of the National Institutes of Health under award number P20GM103471 to WYK. 
Received: 3 September 2015 Accepted: 31 October 2015

Published online: 05 November 2015

\section{References}

1. Martini FJ, Valiente M, Lopez Bendito G, Szabo G, Moya F, Valdeolmillos M, et al. Biased selection of leading process branches mediates chemotaxis during tangential neuronal migration. Development. 2009;136(1):41-50. doi:10.1242/dev.025502.

2. Gleeson JG, Walsh CA. Neuronal migration disorders: from genetic diseases to developmental mechanisms. Trends Neurosci. 2000;23(8):352-9.

3. Kaufmann WE, Moser HW. Dendritic anomalies in disorders associated with mental retardation. Cereb Cortex. 2000;10(10):981-91.

4. Wegiel J, Kuchna I, Nowicki K, Imaki H, Wegiel J, Marchi E, et al. The neuropathology of autism: defects of neurogenesis and neuronal migration, and dysplastic changes. Acta Neuropathol. 2010;119(6):755-70. doi:10.1007/ s00401-010-0655-4.

5. Liu JS. Molecular genetics of neuronal migration disorders. Curr Neurol Neurosci Rep. 2011;11(2):171-8. doi:10.1007/s11910-010-0176-5.

6. Guerrini R, Parrini E. Neuronal migration disorders. Neurobiol Dis. 2010;38(2):154-66. doi:10.1016/j.nbd.2009.02.008

7. Barkovich AJ, Guerrini R, Kuzniecky RI, Jackson GD, Dobyns WB. A developmental and genetic classification for malformations of cortical development: update 2012. Brain. 2012;135(Pt 5):1348-69. doi:10.1093/brain/aws019.

8. Rakic P. Evolution of the neocortex: a perspective from developmental biology. Nat Rev Neurosci. 2009;10(10):724-35. doi:10.1038/nrn2719.

9. Greig LC, Woodworth MB, Galazo MJ, Padmanabhan H, Macklis JD. Molecular logic of neocortical projection neuron specification, development and diversity. Nat Rev Neurosci. 2013;14(11):755-69. doi:10.1038/nrn3586.

10. Franco SJ, Muller U. Shaping our minds: stem and progenitor cell diversity in the mammalian neocortex. Neuron. 2013;77(1):19-34. doi:10.1016/ j.neuron.2012.12.022.

11. Wu Q, Wang X. Neuronal stem cells in the central nervous system and in human diseases. Protein Cell. 2012;3(4):262-70. doi:10.1007/s13238-0122930-8.

12. Tang BL. Molecular genetic determinants of human brain size. Biochem Biophys Res Commun. 2006;345(3):911-6. doi:10.1016/j.bbrc.2006.05.040.

13. Dobyns WB, Stratton RF, Greenberg F. Syndromes with lissencephaly. I: Miller-Dieker and Norman-Roberts syndromes and isolated lissencephaly. Am J Med Genet. 1984;18(3):509-26. doi:10.1002/ajmg.1320180320.

14. Chanas-Sacre G, Rogister B, Moonen G, Leprince P. Radial glia phenotype: origin, regulation, and transdifferentiation. J Neurosci Res. 2000;61(4):357-63.

15. Noctor SC, Flint AC, Weissman TA, Dammerman RS, Kriegstein AR. Neurons derived from radial glial cells establish radial units in neocortex. Nature. 2001;409(6821):714-20. doi:10.1038/35055553.

16. Hartfuss E, Galli R, Heins N, Gotz M. Characterization of CNS precursor subtypes and radial glia. Dev Biol. 2001;229(1):15-30. doi:10.1006/ dbio.2000.9962.

17. Rakic P. Mode of cell migration to the superficial layers of fetal monkey neocortex. J Comp Neurol. 1972;145(1):61-83. doi:10.1002/cne.901450105.

18. Tan SS, Kalloniatis M, Sturm K, Tam PP, Reese BE, Faulkner-Jones B. Separate progenitors for radial and tangential cell dispersion during development of the cerebral neocortex. Neuron. 1998;21(2):295-304.

19. Evsyukova I, Plestant C, Anton ES. Integrative mechanisms of oriented neuronal migration in the developing brain. Annu Rev Cell Dev Biol. 2013;29:299-353. doi:10.1146/annurev-cellbio-101512-122400.

20. Sultan KT, Brown KN, Shi SH. Production and organization of neocortical interneurons. Front Cell Neurosci. 2013;7:221. doi:10.3389/fncel.2013.00221.

21. Anderson SA, Marin O, Horn C, Jennings K, Rubenstein JL. Distinct cortical migrations from the medial and lateral ganglionic eminences. Development. 2001;128(3):353-63.

22. Rakic P. Neuronal migration and contact guidance in the primate telencephalon. Postgrad Med J. 1978;54 Suppl 1:25-40.

23. Molyneaux BJ, Arlotta P, Menezes JR, Macklis JD. Neuronal subtype specification in the cerebral cortex. Nat Rev Neurosci. 2007;8(6):427-37. doi:10.1038/nrn2151.

24. Powell EM, Campbell DB, Stanwood GD, Davis C, Noebels JL, Levitt P. Genetic disruption of cortical interneuron development causes regionand GABA cell type-specific deficits, epilepsy, and behavioral dysfunction. J Neurosci. 2003;23(2):622-31.
25. Bartolini G, Ciceri G, Marin O. Integration of GABAergic interneurons into cortical cell assemblies: lessons from embryos and adults. Neuron. 2013;79(5):849-64. doi:10.1016/j.neuron.2013.08.014.

26. Lodato S, Rouaux C, Quast KB, Jantrachotechatchawan C, Studer M, Hensch TK, et al. Excitatory projection neuron subtypes control the distribution of local inhibitory interneurons in the cerebral cortex. Neuron. 2011;69(4):763-79. doi:10.1016/j.neuron.2011.01.015.

27. Bedogni F, Hodge RD, Elsen GE, Nelson BR, Daza RA, Beyer RP, et al. Tbr1 regulates regional and laminar identity of postmitotic neurons in developing neocortex. Proc Natl Acad Sci U S A. 2010;107(29):13129-34. doi:10.1073/pnas.1002285107.

28. Ghashghaei HT, Lai C, Anton ES. Neuronal migration in the adult brain: are we there yet? Nat Rev Neurosci. 2007;8(2):141-51. doi:10.1038/nrn2074.

29. Taupin P, Gage FH. Adult neurogenesis and neural stem cells of the central nervous system in mammals. J Neurosci Res. 2002;69(6):745-9. doi:10.1002/ jnr.10378.

30. Luskin MB. Restricted proliferation and migration of postnatally generated neurons derived from the forebrain subventricular zone. Neuron. 1993;11(1):173-89.

31. Sanai N, Tramontin AD, Quinones-Hinojosa A, Barbaro NM, Gupta N, Kunwar $\mathrm{S}$, et al. Unique astrocyte ribbon in adult human brain contains neural stem cells but lacks chain migration. Nature. 2004;427(6976):740-4. doi:10.1038/ nature02301.

32. Malagelada C, Lopez-Toledano MA, Willett RT, Jin ZH, Shelanski ML, Greene LA. RTP801/REDD1 regulates the timing of cortical neurogenesis and neuron migration. J Neurosci. 2011;31(9):3186-96. doi:10.1523/ JNEUROSCI.4011-10.2011.

33. Dobyns WB, Truwit CL, Ross ME, Matsumoto N, Pilz DT, Ledbetter DH, et al. Differences in the gyral pattern distinguish chromosome 17-linked and Xlinked lissencephaly. Neurology. 1999;53(2):270-7.

34. Blumcke I, Thom M, Aronica E, Armstrong DD, Vinters HV, Palmini A, et al. The clinicopathologic spectrum of focal cortical dysplasias: a consensus classification proposed by an ad hoc Task Force of the ILAE Diagnostic Methods Commission. Epilepsia. 2011;52(1):158-74. doi:10.1111/j.15281167.2010.02777.x.

35. Hehr U, Uyanik G, Aigner L, Couillard-Despres S, Winkler J. DCX-Related Disorders. In: Pagon RA, Adam MP, Ardinger HH, Bird TD, Dolan CR, Fong $C T$, et al., editors. GeneReviews(R). Seattle (WA): University of Washington; 1993.

36. Toba S, Tamura Y, Kumamoto K, Yamada M, Takao K, Hattori S, et al. Postnatal treatment by a blood-brain-barrier permeable calpain inhibitor, SNJ1945 rescued defective function in lissencephaly. Sci Rep. 2013;3:1224. doi:10.1038/srep01224.

37. Pilz DT, Matsumoto N, Minnerath S, Mills P, Gleeson JG, Allen KM, et al. LIS and XLIS (DCX) mutations cause most classical lissencephaly, but different patterns of malformation. Hum Mol Genet. 1998;7(13):2029-37.

38. des Portes V, Francis F, Pinard JM, Desguerre I, Moutard ML, Snoeck I, et al. doublecortin is the major gene causing $X$-linked subcortical laminar heterotopia (SCLH). Hum Mol Genet. 1998;7(7):1063-70.

39. Gleeson JG, Minnerath SR, Fox JW, Allen KM, Luo RF, Hong SE, et al. Characterization of mutations in the gene doublecortin in patients with double cortex syndrome. Ann Neurol. 1999;45(2):146-53.

40. Kato M, Kimura T, Lin C, Ito A, Kodama S, Morikawa T, et al. A novel mutation of the doublecortin gene in Japanese patients with X-linked lissencephaly and subcortical band heterotopia. Hum Genet. 1999;104(4):341-4.

41. Matsumoto N, Pilz DT, Fantes JA, Kittikamron K, Ledbetter DH. Isolation of BAC clones spanning the Xq22.3 translocation breakpoint in a lissencephaly patient with a de novo X;2 translocation. J Med Genet. 1998;35(10):829-32.

42. Pilz DT, Kuc J, Matsumoto N, Bodurtha J, Bernadi B, Tassinari CA, et al. Subcortical band heterotopia in rare affected males can be caused by missense mutations in DCX (XLIS) or LIS1. Hum Mol Genet. 1999;8(9):1757-60.

43. Dobyns WB, Elias ER, Newlin AC, Pagon RA, Ledbetter DH. Causal heterogeneity in isolated lissencephaly. Neurology. 1992;42(7):1375-88.

44. Horesh D, Sapir T, Francis F, Wolf SG, Caspi M, Elbaum M, et al. Doublecortin, a stabilizer of microtubules. Hum Mol Genet. 1999;8(9):1599-610.

45. Gleeson JG, Lin PT, Flanagan LA, Walsh CA. Doublecortin is a microtubuleassociated protein and is expressed widely by migrating neurons. Neuron. 1999;23(2):257-71.

46. Moores CA, Perderiset M, Francis F, Chelly J, Houdusse A, Milligan RA. Mechanism of microtubule stabilization by doublecortin. Mol Cell. 2004;14(6):833-9. doi:10.1016/j.molcel.2004.06.009. 
47. Deuel TA, Liu JS, Corbo JC, Yoo SY, Rorke-Adams LB, Walsh CA. Genetic interactions between doublecortin and doublecortin-like kinase in neuronal migration and axon outgrowth. Neuron. 2006;49(1):41-53. doi:10.1016/ j.neuron.2005.10.038

48. Tanaka T, Koizumi H, Gleeson JG. The doublecortin and doublecortin-like kinase 1 genes cooperate in murine hippocampal development. Cereb Cortex. 2006;16 Suppl 1:169-73. doi:10.1093/cercor/bhk005.

49. Pramparo $T$, Youn $\mathrm{YH}$, Yingling J, Hirotsune S, Wynshaw-Boris A. Novel embryonic neuronal migration and proliferation defects in Dcx mutant mice are exacerbated by Lis1 reduction. J Neurosci. 2010;30(8):3002-12. doi:10.1523/JNEUROSCI.4851-09.2010.

50. Gleeson JG, Allen KM, Fox JW, Lamperti ED, Berkovic S, Scheffer I, et al. Doublecortin, a brain-specific gene mutated in human X-linked lissencephaly and double cortex syndrome, encodes a putative signaling protein. Cell. 1998:92(1):63-72.

51. Wynshaw-Boris A, Pramparo T, Youn YH, Hirotsune S. Lissencephaly: mechanistic insights from animal models and potential therapeutic strategies Semin Cell Dev Biol. 2010;21(8):823-30. doi:10.1016/j.semcdb.2010.07.008.

52. Jang MA, Woo HI, Kim JW, Lee J, Ki CS. Identification of DCX gene mutation in lissencephaly spectrum with subcortical band heterotopia using whole exome sequencing. Pediatr Neurol. 2013;48(5):411-4. doi:10.1016/ j.pediatrneurol.2012.12.033.

53. Taylor KR, Holzer AK, Bazan JF, Walsh CA, Gleeson JG. Patient mutations in doublecortin define a repeated tubulin-binding domain. J Biol Chem. 2000;275(44):34442-50. doi:10.1074/jbc.M007078200.

54. Moon HM, Wynshaw-Boris A. Cytoskeleton in action: lissencephaly, a neuronal migration disorder. Wiley Interdiscip Rev Dev Biol. 2013;2(2):229-45. doi:10.1002/wdev.67.

55. Pilz DT, Macha ME, Precht KS, Smith AC, Dobyns WB, Ledbetter DH. Fluorescence in situ hybridization analysis with LIS1 specific probes reveals a high deletion mutation rate in isolated lissencephaly sequence. Genet Med. 1998;1(1):29-33. doi:10.1097/00125817-199811000-00007.

56. Reiner $O$, Carrozzo R, Shen $Y$, Wehnert M, Faustinella F, Dobyns WB, et al. Isolation of a Miller-Dieker lissencephaly gene containing $G$ protein beta-subunit-like repeats. Nature. 1993;364(6439):717-21. doi:10.1038/364717a0

57. Wynshaw-Boris A. Lissencephaly and LIS1: insights into the molecular mechanisms of neuronal migration and development. Clin Genet. 2007;72(4):296-304. doi:10.1111/j.1399-0004.2007.00888.x.

58. Reiner O, Sapir T. LIS1 functions in normal development and disease. Curr Opin Neurobiol. 2013;23(6):951-6. doi:10.1016/j.conb.2013.08.001.

59. Siller $\mathrm{KH}$, Doe CQ. Lis1/dynactin regulates metaphase spindle orientation in Drosophila neuroblasts. Dev Biol. 2008;319(1):1-9. doi:10.1016/ j.ydbio.2008.03.018.

60. Yingling J, Youn YH, Darling D, Toyo-Oka K, Pramparo T, Hirotsune S, et al. Neuroepithelial stem cell proliferation requires LIS1 for precise spindle orientation and symmetric division. Cell. 2008;132(3):474-86. doi:10.1016/ j.cell.2008.01.026

61. Moon HM, Youn YH, Pemble H, Yingling J, Wittmann T, Wynshaw-Boris A. LIS1 controls mitosis and mitotic spindle organization via the LIS1-NDEL1dynein complex. Hum Mol Genet. 2014;23(2):449-66. doi:10.1093/hmg/ ddt436.

62. Saillour Y, Carion N, Quelin C, Leger PL, Boddaert N, Elie C, et al. LIS1-related isolated lissencephaly: spectrum of mutations and relationships with malformation severity. Arch Neurol. 2009;66(8):1007-15. doi:10.1001/ archneurol.2009.149.

63. Grabham PW, Seale GE, Bennecib M, Goldberg DJ, Vallee RB. Cytoplasmic dynein and LIS1 are required for microtubule advance during growth cone remodeling and fast axonal outgrowth. J Neurosci. 2007;27(21):5823-34. doi:10.1523/JNEUROSCI.1135-07.2007.

64. Pang T, Atefy R, Sheen V. Malformations of cortical development. Neurologist. 2008;14(3):181-91. doi:10.1097/NRL.0b013e31816606b9.

65. Cardoso C, Leventer RJ, Matsumoto N, Kuc JA, Ramocki MB, Mewborn SK, et al. The location and type of mutation predict malformation severity in isolated lissencephaly caused by abnormalities within the LIS1 gene. Hum Mol Genet. 2000:9(20):3019-28.

66. Jaglin XH, Poirier K, Saillour Y, Buhler E, Tian G, Bahi-Buisson N, et al. Mutations in the beta-tubulin gene TUBB2B result in asymmetrical polymicrogyria. Nat Genet. 2009;41(6):746-52. doi:10.1038/ng.380.

67. Kumar RA, Pilz DT, Babatz TD, Cushion TD, Harvey K, Topf M, et al. TUBA1A mutations cause wide spectrum lissencephaly (smooth brain) and suggest that multiple neuronal migration pathways converge on alpha tubulins. Hum Mol Genet. 2010;19(14):2817-27. doi:10.1093/hmg/ddq182.

68. Sohal AP, Montgomery T, Mitra D, Ramesh V. TUBA1A mutation-associated lissencephaly: case report and review of the literature. Pediatr Neurol. 2012;46(2):127-31. doi:10.1016/j.pediatrneurol.2011.11.017

69. Hikita N, Hattori H, Kato M, Sakuma S, Morotomi Y, Ishida H, et al. A case of TUBA1A mutation presenting with lissencephaly and Hirschsprung disease. Brain Dev. 2014;36(2):159-62. doi:10.1016/j.braindev.2013.02.006.

70. Guerrini R, Mei D, Cordelli DM, Pucatti D, Franzoni E, Parrini E. Symmetric polymicrogyria and pachygyria associated with TUBB2B gene mutations. Eur J Hum Genet. 2012;20(9):995-8. doi:10.1038/ejhg.2012.21.

71. Arai T, Kaziro Y. Role of GTP in the assembly of microtubules. J Biochem. 1977;82(4):1063-71.

72. Keays DA, Tian G, Poirier K, Huang GJ, Siebold C, Cleak J, et al. Mutations in alpha-tubulin cause abnormal neuronal migration in mice and lissencephaly in humans. Cell. 2007;128(1):45-57. doi:10.1016/j.cell.2006.12.017.

73. Tischfield MA, Baris HN, Wu C, Rudolph G, Van Maldergem L, He W, et al. Human TUBB3 mutations perturb microtubule dynamics, kinesin interactions, and axon quidance. Cell. 2010;140(1):74-87. doi:10.1016/i.cell.2009.12.011.

74. Miura H, Yanazawa M, Kato K, Kitamura K. Expression of a novel aristaless related homeobox gene 'Arx' in the vertebrate telencephalon, diencephalon and floor plate. Mech Dev. 1997;65(1-2):99-109.

75. Colasante G, Simonet JC, Calogero R, Crispi S, Sessa A, Cho G, et al. ARX Regulates Cortical Intermediate Progenitor Cell Expansion and Upper Layer Neuron Formation Through Repression of Cdkn1c. Cereb Cortex. 2013. doi:10.1093/cercor/bht222

76. Simonet JC, Sunnen CN, Wu J, Golden JA, Marsh ED. Conditional Loss of Arx From the Developing Dorsal Telencephalon Results in Behavioral Phenotypes Resembling Mild Human ARX Mutations. Cereb Cortex. 2014 doi:10.1093/cercor/bhu090

77. Abedini SS, Kahrizi K, Behjati F, Banihashemi S, Ghasemi Firoozabadi S, Najmabadi H. Mutational screening of ARX gene in Iranian families with $X$ linked intellectual disability. Arch Iran Med. 2012;15(6):361-5. doi:012156/ AlM.009.

78. Charzewska A, Nawara M, Jakubiuk-Tomaszuk A, Obersztyn E, HoffmanZacharska D, Elert E, et al. Expanding the phenotype associated with missense mutations of the ARX gene. Am J Med Genet A. 2013;161A(7):1813-6. doi:10.1002/ajmg.a.36003.

79. Kato M, Dobyns WB. Lissencephaly and the molecular basis of neuronal migration. Hum Mol Genet. 2003;12(Spec No 1):R89-96.

80. Kitamura K, Yanazawa M, Sugiyama N, Miura H, lizuka-Kogo A, Kusaka M, et al. Mutation of ARX causes abnormal development of forebrain and testes in mice and X-linked lissencephaly with abnormal genitalia in humans. Nat Genet. 2002;32(3):359-69. doi:10.1038/ng1009.

81. Shoubridge C, Fullston T, Gecz J. ARX spectrum disorders: making inroads into the molecular pathology. Hum Mutat. 2010;31(8):889-900. doi:10.1002/ humu.21288.

82. Friocourt G, Kanatani S, Tabata H, Yozu M, Takahashi T, Antypa M, et al. Cell-autonomous roles of ARX in cell proliferation and neuronal migration during corticogenesis. J Neurosci. 2008;28(22):5794-805. doi:10.1523/ JNEUROSCl.1067-08.2008.

83. Marsh E, Fulp C, Gomez E, Nasrallah I, Minarcik J, Sudi J, et al. Targeted loss of Arx results in a developmental epilepsy mouse model and recapitulates the human phenotype in heterozygous females. Brain. 2009;132(Pt 6):1563-76. doi:10.1093/brain/awp107.

84. Vogt D, Hunt RF, Mandal S, Sandberg M, Silberberg SN, Nagasawa T, et al. Lhx6 directly regulates Arx and CXCR7 to determine cortical interneuron fate and laminar position. Neuron. 2014:82(2):350-64. doi:10.1016/ j.neuron.2014.02.030

85. Olivetti PR, Noebels JL. Interneuron, interrupted: molecular pathogenesis of ARX mutations and X-linked infantile spasms. Curr Opin Neurobiol. 2012;22(5):859-65. doi:10.1016/j.conb.2012.04.006

86. Friocourt $\mathrm{G}$, Parnavelas JG. Identification of Arx targets unveils new candidates for controlling cortical interneuron migration and differentiation. Front Cell Neurosci. 2011;5:28. doi:10.3389/fnbeh.2011.00028.

87. Beguin $\mathrm{S}$, Crepel V, Aniksztejn L, Becq H, Pelosi B, Pallesi-Pocachard E, et al. An epilepsy-related ARX polyalanine expansion modifies glutamatergic neurons excitability and morphology without affecting GABAergic neurons development. Cereb Cortex. 2013;23(6):1484-94. doi:10.1093/cercor/bhs138.

88. D'Arcangelo G, Homayouni R, Keshvara L, Rice DS, Sheldon M, Curran T. Reelin is a ligand for lipoprotein receptors. Neuron. 1999;24(2):471-9. 
89. Frotscher M. Cajal-Retzius cells, Reelin, and the formation of layers. Curr Opin Neurobiol. 1998;8(5):570-5.

90. Tissir F, Goffinet AM. Reelin and brain development. Nat Rev Neurosci. 2003:4(6):496-505. doi:10.1038/nrn1113.

91. Forster $E$, Jossin $Y$, Zhao S, Chai X, Frotscher M, Goffinet AM. Recent progress in understanding the role of Reelin in radial neuronal migration, with specific emphasis on the dentate gyrus. Eur J Neurosci. 2006;23(4):901-9. doi:10.1111/j.1460-9568.2006.04612.x

92. Sharaf A, Bock HH, Spittau B, Bouche E, Krieglstein K. ApoER2 and VLDLr are required for mediating reelin signalling pathway for normal migration and positioning of mesencephalic dopaminergic neurons. PLoS One. 2013;8(8):e71091. doi:10.1371/journal.pone.0071091.

93. Niu S, Renfro A, Quattrocchi CC, Sheldon M, D'Arcangelo G. Reelin promotes hippocampal dendrite development through the VLDLR/ApoER2Dab1 pathway. Neuron. 2004;41(1):71-84.

94. Hong SE, Shugart YY, Huang DT, Shahwan SA, Grant PE, Hourihane JO, et al. Autosomal recessive lissencephaly with cerebellar hypoplasia is associated with human RELN mutations. Nat Genet. 2000;26(1):93-6. doi:10.1038/79246.

95. Ozcelik T, Akarsu N, Uz E, Caglayan S, Gulsuner S, Onat OE, et al. Mutations in the very low-density lipoprotein receptor VLDLR cause cerebellar hypoplasia and quadrupedal locomotion in humans. Proc Natl Acad Sci U S A. 2008;105(11):4232-6. doi:10.1073/pnas.0710010105.

96. Folsom TD, Fatemi SH. The involvement of Reelin in neurodevelopmental disorders. Neuropharmacology. 2013;68:122-35. doi:10.1016/ j.neuropharm.2012.08.015.

97. Boycott KM, Bonnemann C, Herz J, Neuert S, Beaulieu C, Scott JN, et al. Mutations in VLDLR as a cause for autosomal recessive cerebellar ataxia with mental retardation (dysequilibrium syndrome). J Child Neurol. 2009;24(10):1310-5. doi:10.1177/0883073809332696.

98. Palomero-Dominguez MA, Ramos-Fernandez JM, Dominguez-Santurino F, Ruiz-Gomez M. Type II lissencephaly: presentation of intermediate form. Rev Neurol. 1998;27(158):594-6.

99. Dobyns WB, Kirkpatrick JB, Hittner HM, Roberts RM, Kretzer FL. Syndromes with lissencephaly. II: Walker-Warburg and cerebro-oculo-muscular syndromes and a new syndrome with type II lissencephaly. Am J Med Genet. 1985;22(1):157-95. doi:10.1002/ajmg.1320220118.

100. Aida N. Fukuyama congenital muscular dystrophy: a neuroradiologic review. J Magn Reson Imaging. 1998;8(2):317-26.

101. Vajsar J, Schachter H. Walker-Warburg syndrome. Orphanet J Rare Dis. 2006;1:29. doi:10.1186/1750-1172-1-29.

102. Herman TE, Siegel MJ. Miller-Dieker syndrome, type 1 lissencephaly. J Perinatol. 2008;28(4):313-5. doi:10.1038/sj.jp.7211920.

103. Yoshida A, Kobayashi K, Manya H, Taniguchi K, Kano H, Mizuno M, et al. Muscular dystrophy and neuronal migration disorder caused by mutations in a glycosyltransferase, POMGnT1. Dev Cell. 2001;1(5):717-24.

104. Fuchs-Telem D, Stewart H, Rapaport D, Nousbeck J, Gat A, Gini M, et al. CEDNIK syndrome results from loss-of-function mutations in SNAP29. Br J Dermatol. 2011;164(3):610-6. doi:10.1111/j.1365-2133.2010.10133.x.

105. Sprecher E, Ishida-Yamamoto A, Mizrahi-Koren M, Rapaport D, Goldsher D, Indelman M, et al. A mutation in SNAP29, coding for a SNARE protein involved in intracellular trafficking, causes a novel neurocutaneous syndrome characterized by cerebral dysgenesis, neuropathy, ichthyosis, and palmoplantar keratoderma. Am J Hum Genet. 2005;77(2):242-51. doi:10.1086/432556.

106. Rapaport D, Lugassy Y, Sprecher E, Horowitz M. Loss of SNAP29 impairs endocytic recycling and cell motility. PLoS One. 2010;5(3):e9759. doi:10.1371/journal.pone.0009759.

107. Guerrini R, Filippi T. Neuronal migration disorders, genetics, and epileptogenesis. J Child Neurol. 2005;20(4):287-99.

108. Verrotti A, Spalice A, Ursitti F, Papetti L, Mariani R, Castronovo A, et al. New trends in neuronal migration disorders. Eur J Paediatr Neurol. 2010;14(1):1-12. doi:10.1016/j.ejpn.2009.01.005.

109. Murdock DR, Clark GD, Bainbridge MN, Newsham I, Wu YQ, Muzny DM, et al. Whole-exome sequencing identifies compound heterozygous mutations in WDR62 in siblings with recurrent polymicrogyria. Am J Med Genet A. 2011;155A(9):2071-7. doi:10.1002/ajmg.a.34165.

110. Bhat V, Girimaji SC, Mohan G, Arvinda HR, Singhmar P, Duvvari MR, et al. Mutations in WDR62, encoding a centrosomal and nuclear protein, in Indian primary microcephaly families with cortical malformations. Clin Genet. 2011;80(6):532-40. doi:10.1111/j.1399-0004.2011.01686.x.
111. Jansen A, Andermann E. Genetics of the polymicrogyria syndromes. J Med Genet. 2005;42(5):369-78. doi:10.1136/jmg.2004.023952.

112. Barkovich AJ, Kuzniecky RI, Jackson GD, Guerrini R, Dobyns WB. Classification system for malformations of cortical development: update 2001. Neurology. 2001;57(12):2168-78.

113. Guerreiro MM, Andermann E, Guerrini R, Dobyns WB, Kuzniecky R, Silver K, et al. Familial perisylvian polymicrogyria: a new familial syndrome of cortical maldevelopment. Ann Neurol. 2000;48(1):39-48.

114. Chang BS, Piao X, Giannini C, Cascino GD, Scheffer I, Woods CG, et al. Bilateral generalized polymicrogyria (BGP): a distinct syndrome of cortical malformation. Neurology. 2004;62(10):1722-8.

115. Dobyns WB, Mirzaa G, Christian SL, Petras K, Roseberry J, Clark GD, et al. Consistent chromosome abnormalities identify novel polymicrogyria loci in 1p36.3, 2p16.1-p23.1, 4q21.21-q22.1, 6q26-q27, and 21q2. Am J Med Genet A. 2008;146A(13):1637-54. doi:10.1002/ajmg.a.32293.

116. Robin NH, Taylor CJ, McDonald-McGinn DM, Zackai EH, Bingham P, Collins $\mathrm{KJ}$, et al. Polymicrogyria and deletion 22q11.2 syndrome: window to the etiology of a common cortical malformation. Am J Med Genet A. 2006;140(22):2416-25. doi:10.1002/ajmg.a.31443.

117. Englund C, Fink A, Lau C, Pham D, Daza RA, Bulfone A, et al. Pax6, Tbr2, and Tbr1 are expressed sequentially by radial glia, intermediate progenitor cells, and postmitotic neurons in developing neocortex. J Neurosci. 2005:25(1):247-51. doi:10.1523/JNEUROSCI.2899-04.2005.

118. Mitchell TN, Free SL, Williamson KA, Stevens JM, Churchill AJ, Hanson IM, et al. Polymicrogyria and absence of pineal gland due to PAX6 mutation. Ann Neurol. 2003;53(5):658-63. doi:10.1002/ana.10576.

119. Baala L, Briault S, Etchevers HC, Laumonnier F, Natiq A, Amiel J, et al. Homozygous silencing of T-box transcription factor EOMES leads to microcephaly with polymicrogyria and corpus callosum agenesis. Nat Genet. 2007;39(4):454-6. doi:10.1038/ng1993.

120. Manuel MN, Mi D, Mason JO, Price DJ. Regulation of cerebral cortical neurogenesis by the Pax6 transcription factor. Front Cell Neurosci. 2015;9:70. doi:10.3389/fncel.2015.00070.

121. Roll P, Rudolf G, Pereira S, Royer B, Scheffer IE, Massacrier A, et al. SRPX2 mutations in disorders of language cortex and cognition. Hum Mol Genet. 2006;15(7):1195-207. doi:10.1093/hmg/ddl035.

122. Brooks AS, Bertoli-Avella AM, Burzynski GM, Breedveld GJ, Osinga J, Boven LG, et al. Homozygous nonsense mutations in KIAA1279 are associated with malformations of the central and enteric nervous systems. Am J Hum Genet. 2005;77(1):120-6. doi:10.1086/431244

123. Drevillon L, Megarbane A, Demeer B, Matar C, Benit P, Briand-Suleau A, et al. KBP-cytoskeleton interactions underlie developmental anomalies in Goldberg-Shprintzen syndrome. Hum Mol Genet. 2013;22(12):2387-99. doi:10.1093/hmg/ddt083

124. Dafsari HS, Byrne S, Lin JP, Pitt M, Jongbloed JD, Flinter F, et al. GoldbergShprintzen megacolon syndrome with associated sensory motor axonal neuropathy. Am J Med Genet A. 2015;167(6):1300-4. doi:10.1002/ajmg.a.36873.

125. Aligianis IA, Johnson CA, Gissen P, Chen D, Hampshire D, Hoffmann K, et al. Mutations of the catalytic subunit of RAB3GAP cause Warburg Micro syndrome. Nat Genet. 2005;37(3):221-3. doi:10.1038/ng1517.

126. Handley MT, Carpanini SM, Mali GR, Sidjanin DJ, Aligianis IA, Jackson IJ, et al. Warburg Micro syndrome is caused by RAB18 deficiency or dysregulation. Open Biol. 2015;5(6):150047. doi:10.1098/rsob.150047.

127. Reinstein E, Chang BS, Robertson SP, Rimoin DL, Katzir T. Filamin A mutation associated with normal reading skills and dyslexia in a family with periventricular heterotopia. Am J Med Genet A. 2012;158A(8):1897-901. doi:10.1002/ajmg.a.35455.

128. Chang BS, Katzir T, Liu T, Corriveau K, Barzillai M, Apse KA, et al. A structural basis for reading fluency: white matter defects in a genetic brain malformation. Neurology. 2007:69(23):2146-54. doi:10.1212/01.wnl.0000286365.41070.54.

129. Robertson SP. Filamin A: phenotypic diversity. Curr Opin Genet Dev. 2005;15(3):301-7. doi:10.1016/j.gde.2005.04.001.

130. Fox JW, Lamperti ED, Eksioglu YZ, Hong SE, Feng Y, Graham DA, et al. Mutations in filamin 1 prevent migration of cerebral cortical neurons in human periventricular heterotopia. Neuron. 1998;21(6):1315-25.

131. Zhang J, Neal J, Lian G, Hu J, Lu J, Sheen V. Filamin A regulates neuronal migration through brefeldin A-inhibited guanine exchange factor 2dependent Arf1 activation. J Neurosci. 2013;33(40):15735-46. doi:10.1523/ JNEUROSCI.1939-13.2013

132. Nagata D, Takeda R, Sata M, Satonaka H, Suzuki E, Nagano T, et al. AMPactivated protein kinase inhibits angiotensin II-stimulated vascular smooth 
muscle cell proliferation. Circulation. 2004;110(4):444-51. doi:10.1161/ 01.CIR.0000136025.96811.76.

133. Parrini E, Ramazzotti A, Dobyns WB, Mei D, Moro F, Veggiotti $P$, et al. Periventricular heterotopia: phenotypic heterogeneity and correlation with Filamin A mutations. Brain. 2006;129(Pt 7):1892-906. doi:10.1093/brain/awl125.

134. Sheen VL, Dixon PH, Fox JW, Hong SE, Kinton L, Sisodiya SM, et al. Mutations in the $\mathrm{X}$-linked filamin 1 gene cause periventricular nodular heterotopia in males as well as in females. Hum Mol Genet. 2001;10(17):1775-83.

135. Gomez-Garre P, Serratosa JM. Gene symbol: FLNA. Disease: Ehlers-Danlos syndrome and periventricular nodular heterotopia. Hum Genet. 2005;118(3-4):545.

136. Verrotti A, Monacelli D, Castagnino M, Villa MP, Parisi P. Ehlers-Danlos syndrome: a cause of epilepsy and periventricular heterotopia. Seizure. 2014;23(10):819-24. doi:10.1016/j.seizure.2014.07.014.

137. Sheen VL, Wheless JW, Bodell A, Braverman E, Cotter PD, Rauen KA, et al. Periventricular heterotopia associated with chromosome $5 p$ anomalies. Neurology. 2003;60(6):1033-6.

138. Moro F, Pisano T, Bernardina BD, Polli R, Murgia A, Zoccante L, et al. Periventricular heterotopia in fragile $X$ syndrome. Neurology. 2006;67(4):713-5. doi:10.1212/01.wnl.0000230223.51595.99

139. Togawa A, Morinaga N, Ogasawara M, Moss J, Vaughan M. Purification and cloning of a brefeldin A-inhibited guanine nucleotide-exchange protein for ADP-ribosylation factors. J Biol Chem. 1999;274(18):12308-15.

140. Sheen VL. Filamin A, mediated Big2 dependent endocytosis: From apical abscission to periventricular heterotopia. Tissue Barriers. 2014;2:e29431. doi:10.4161/tisb.29431.

141. Sheen VL, Ganesh VS, Topcu M, Sebire G, Bodell A, Hill RS, et al. Mutations in ARFGEF2 implicate vesicle trafficking in neural progenitor proliferation and migration in the human cerebral cortex. Nat Genet. 2004;36(1):69-76. doi:10.1038/ng1276.

142. Kantarci S, Al-Gazali L, Hill RS, Donnai D, Black GC, Bieth E, et al. Mutations in LRP2, which encodes the multiligand receptor megalin, cause DonnaiBarrow and facio-oculo-acoustico-renal syndromes. Nat Genet. 2007;39(8):957-9. doi:10.1038/ng2063.

143. McCarthy RA, Barth JL, Chintalapudi MR, Knaak C, Argraves WS. Megalin functions as an endocytic sonic hedgehog receptor. J Biol Chem. 2002;277(28):25660-7. doi:10.1074/jbc.M201933200.

144. Christ A, Christa A, Kur E, Lioubinski O, Bachmann S, Willnow TE, et al. LRP2 is an auxiliary $\mathrm{SHH}$ receptor required to condition the forebrain ventral midline for inductive signals. Dev Cell. 2012;22(2):268-78. doi:10.1016/ j.devcel.2011.11.023.

145. Kabat J, Krol P. Focal cortical dysplasia - review. Pol J Radiol. 2012;77(2):35-43.

146. Ying Z, Gonzalez-Martinez J, Tilelli C, Bingaman W, Najm I. Expression of neural stem cell surface marker CD133 in balloon cells of human focal cortical dysplasia. Epilepsia. 2005;46(11):1716-23. doi:10.1111/j.15281167.2005.00276.x

147. Najm IM, Tilelli CQ, Oghlakian R. Pathophysiological mechanisms of focal cortical dysplasia: a critical review of human tissue studies and animal models. Epilepsia. 2007:48 Suppl 2:21-32.

148. Palmini A, Najm I, Avanzini G, Babb T, Guerrini R, Foldvary-Schaefer N, et al. Terminology and classification of the cortical dysplasias. Neurology. 2004;62(6 Suppl 3):S2-8.

149. Taylor DC, Falconer MA, Bruton CJ, Corsellis JA. Focal dysplasia of the cerebral cortex in epilepsy. J Neurol Neurosurg Psychiatry. 1971;34(4):369-87.

150. Fassunke J, Blumcke I, Lahl R, Elger CE, Schramm J, Merkelbach-Bruse S, et al. Analysis of chromosomal instability in focal cortical dysplasia of Taylor's balloon cell type. Acta Neuropathol. 2004;108(2):129-34. doi:10.1007/s00401-004-0874-7.

151. Becker AJ, Urbach H, Scheffler B, Baden T, Normann S, Lahl R, et al. Focal cortical dysplasia of Taylor's balloon cell type: mutational analysis of the TSC1 gene indicates a pathogenic relationship to tuberous sclerosis. Ann Neurol. 2002;52(1):29-37. doi:10.1002/ana.10251.

152. Cotter D, Honavar M, Lovestone S, Raymond L, Kerwin R, Anderton B, et al. Disturbance of Notch-1 and Wnt signalling proteins in neuroglial balloon cells and abnormal large neurons in focal cortical dysplasia in human cortex. Acta Neuropathol. 1999;98(5):465-72.

153. Sato $N$, Yagishita A, Oba H, Miki Y, Nakata Y, Yamashita F, et al. Hemimegalencephaly: a study of abnormalities occurring outside the involved hemisphere. AJNR Am J Neuroradiol. 2007;28(4):678-82.
154. Hengst M, Tucke J, Zerres K, Blaum M, Hausler M. Megalencephaly, mega corpus callosum, and complete lack of motor development: delineation of a rare syndrome. Am J Med Genet A. 2010;152A(9):2360-4. doi:10.1002/ ajmg.a.33577.

155. Woo CL, Chuang SH, Becker LE, Jay V, Otsubo H, Rutka JT, et al. Radiologicpathologic correlation in focal cortical dysplasia and hemimegalencephaly in 18 children. Pediatr Neurol. 2001;25(4):295-303.

156. Flores-Sarnat L. Hemimegalencephaly: part 1. Genetic, clinical, and imaging aspects. J Child Neurol. 2002;17(5):373-84. discussion 84.

157. D'Agostino MD, Bastos A, Piras C, Bernasconi A, Grisar T, Tsur VG, et al. Posterior quadrantic dysplasia or hemi-hemimegalencephaly: a characteristic brain malformation. Neurology. 2004;62(12):2214-20.

158. Barkovich AJ, Chuang SH. Unilateral megalencephaly: correlation of MR imaging and pathologic characteristics. AJNR Am J Neuroradiol. 1990;11(3):523-31.

159. Takashima S, Chan F, Becker LE, Kuruta H. Aberrant neuronal development in hemimegalencephaly: immunohistochemical and Golgi studies. Pediatr Neurol. 1991;7(4):275-80.

160. Lee JH, Huynh M, Silhavy JL, Kim S, Dixon-Salazar T, Heiberg A, et al. De novo somatic mutations in components of the PI3K-AKT3-mTOR pathway cause hemimegalencephaly. Nat Genet. 2012;44(8):941-5. doi:10.1038/ng.2329

161. Poduri A, Evrony GD, Cai X, Elhosary PC, Beroukhim R, Lehtinen MK, et al. Somatic activation of AKT3 causes hemispheric developmental brain malformations. Neuron. 2012;74(1):41-8. doi:10.1016/j.neuron.2012.03.010.

162. Riviere JB, Mirzaa GM, O'Roak BJ, Beddaoui M, Alcantara D, Conway RL, et al. De novo germline and postzygotic mutations in AKT3, PIK3R2 and PIK3CA cause a spectrum of related megalencephaly syndromes. Nat Genet. 2012;44(8):934-40. doi:10.1038/ng.2331.

163. Biesecker LG, Spinner NB. A genomic view of mosaicism and human disease. Nat Rev Genet. 2013;14(5):307-20. doi:10.1038/nrg3424.

164. Baek ST, Gibbs EM, Gleeson JG, Mathern GW. Hemimegalencephaly, a paradigm for somatic postzygotic neurodevelopmental disorders. Curr Opin Neurol. 2013;26(2):122-7. doi:10.1097/WCO.0b013e32835ef373.

165. Groszer M, Erickson R, Scripture-Adams DD, Lesche R, Trumpp A, Zack JA, et al. Negative regulation of neural stem/progenitor cell proliferation by the Pten tumor suppressor gene in vivo. Science. 2001;294(5549):2186-9. doi:10.1126/science.1065518.

166. Segarra J, Balenci L, Drenth T, Maina F, Lamballe F. Combined signaling through ERK, PI3K/AKT, and RAC1/p38 is required for met-triggered cortical neuron migration. J Biol Chem. 2006;281(8):4771-8. doi:10.1074/ jbc.M508298200.

167. Amiri A, Cho W, Zhou J, Birnbaum SG, Sinton CM, McKay RM, et al. Pten deletion in adult hippocampal neural stem/progenitor cells causes cellular abnormalities and alters neurogenesis. J Neurosci. 2012;32(17):5880-90. doi:10.1523/JNEUROSCI.5462-11.2012.

168. Magri L, Cambiaghi M, Cominelli M, Alfaro-Cervello C, Cursi M, Pala M, et al. Sustained activation of mTOR pathway in embryonic neural stem cells leads to development of tuberous sclerosis complex-associated lesions. Cell Stem Cell. 2011;9(5):447-62. doi:10.1016/j.stem.2011.09.008.

\section{Submit your next manuscript to BioMed Central and take full advantage of:}

- Convenient online submission

- Thorough peer review

- No space constraints or color figure charges

- Immediate publication on acceptance

- Inclusion in PubMed, CAS, Scopus and Google Scholar

- Research which is freely available for redistribution 